\title{
THE RELATIONSHIP BETWEEN CELEBRITY WORSHIP AND BODY IMAGE ADOLESCENT WHO IDOLIZE K-POP
}

\author{
Rizkia Nur Utami ${ }^{1}$
}

\begin{abstract}
The background of this study is to research the relationship between celebrity worship and body image among student who likes K-pop. Celebrity worship is a phenomenon of individual admission to a celebrity and body image is individual perception of the state of the body. The research intends to describe the relationship between celebrity worship and body image adolescents who idolize K-pop at SMP Negeri 45 Bandung. The approach used in this research is a quantitative and correlational method. The participants are 111 adolescents who idolize K-pop, using purposive sampling. Data in this research collected using an instrument of celebrity worship and body image. processing data using the Rasch model in the winstep application. The result of this research signifies the celebrity worship in the moderate category with a percentage of $43,24 \%$, body image in the positive category with a percentage of $56,8 \%$, and there was a quite negatively significant relationship between celebrity worship and body image. The result of this research are recommendations for school counsellors and future researcher.
\end{abstract}

Keywords: Celebrity Worship, Body Image, Adolescents.

JOMSIGN: Journal of Multicultural Studies in Guidance and Counseling Website: http://ejournal.upi.edu/index.php/JOMSIGN

Permalink: http://ejournal.upi.edu/index.php/JOMSIGN/article/view/6314

How to cite (APA): Utami, R., N. (2019). The Relationship Between Celebrity Worship and Body Image Adolescent Who Idolize K-Pop. JOMSIGN: Journal of Multicultural Studies in Guidance and Counseling, 3(2), 137-150.

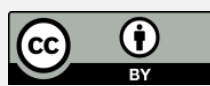

This is an open-access article distributed under the terms of the Creative Commons Attribution 4.0 International License, which permits unrestricted use, distribution, and reproduction in any medium, provided the original work is properly cited.

\section{INTRODUCTION}

At each stage of life, every individual has a variety of problems both problems that arise from himself, others or come from the environment. The stage of an individual's life that is usually filled with storms with various complex problems and real changes. This stage of life is adolescence. Adolescence is a period of developmental transition between childhood and adulthood, which involves biological, cognitive, and socio-emotional changes that are marked by clearly visible physical changes (Santrock, 2012 in Frederika, 2015, p. 62).

\footnotetext{
${ }^{1}$ Universitas Pendidikan Indonesia, Indonesia; rizkianuru@student.upi.edu
} 
The phenomenon that often occurs in adolescence one of which is the Korean wave. The Korean wave is usually a fan of K-pop music which of course is mostly dominated by teenagers. In this process, it shows that adolescents need exemplary figures so that they can imitate these figures. Idols become the background of changes in adolescent behaviour to match the environmental demands of peers who have the same idol (Ninggalih, 2011). One of the psychological effects of changes in the body during adolescence is the feeling of anxiety with their bodies so as to form a body image of the condition of their bodies (Rombe, 2014, p. 79).

Female adolescents between the age range 12-17 years old in America, there are $40-70 \%$ of adolescent girls feel less satisfied with their body parts and also $50-80 \%$ of adolescent girls want to be thinner than before, while some other teenagers who have negative body image go on a strict diet in order to obtain the ideal body (Levine \& Smolak in Cash, 2002, p. 74).

In addition, there are also other ways that individuals do to have satisfaction with body image by changing their body shape. As in research conducted by Nerissaputri (2015), a teenager who is a participant is a teenager who performs plastic surgery to be the same as his idol artist. Many attempts are made by adolescents to have an ideal and proportional body image and to be thin, one of the ways that are usually done by doing diet and gym (Dacey and Kenny, 2001).

Besides that, adolescents have the task of developing their lives, among others, accepting their own physique, achieving emotional independence from figures, finding humans as models and strengthening self-control (Sunami, 2015). The statement in the study raised concerns about the phenomenon of Kpop, especially in adolescents who generally, when entering adolescence, many adolescents, especially adolescent girls who are less satisfied with their physical condition or can be said to have a negative body image. Negative body image means dissatisfaction with some aspects of one's physical appearance (Cash in Cash \& Fruzinsky, 2002, p. 269) in other words, there are several aspects of one's appearance that are evaluated negatively. This is in line with what Santrock said (2012, p. 406) that at puberty is a period where adolescents are less satisfied with their bodies and have a more negative image on the body, especially adolescent girls. Phenomenon and some of these statements are important but there is still not a lot of research related to body image with celebrity worship, it makes researchers will examine the 
relationship between body image with celebrity worship after some of the statements and phenomena.

Based on the impact obtained from celebrity worship behaviour and body image it means that both of these behaviours have a negative impact that will hinder the development of adolescents themselves so that it will inhibit adolescents in developing their potential. Celebrity worship behaviour and negative body image will disrupt adolescents in the psychological aspects of adolescents and this is one of the tasks of counsellors and counselling guidance teachers to prepare to conduct counselling as prevention of adolescents so that they have a positive body image and conduct counselling as assistance for adolescents who do celebrity worship at the highest stage. Positive body image is owned by individuals who are satisfied with their physical condition (Smolak in Cash \& Pruzinsky, 2002).

Celebrity worship and body image are the personal and psychological domains of students. Teachers in schools that have the task of facilitating the psychological development of participants and in the personal development of students are teachers of guidance and counselling. The purpose of guidance and counselling services is the realization of students who believe, fear God, be virtuous, intelligent, have knowledge and skills, have physical and spiritual health, a steady, independent and responsible personality (Depdiknas, 2008, p. 218). Guidance and counselling teachers are tasked with facilitating the development of students to have intellectual and skilled abilities, understand their strengths and weaknesses, have a noble character, be mentally healthy and have good personalities. Students are expected to become individuals who have intellectual intelligence, emotional intelligence and spiritual intelligence (Yusuf, 2014).

Lately, teenagers are often attracted to celebrity idols excessively called celebrity worship. The concern that arises because of this phenomenon is a negative body image. Negative body image also results in body dysmorphic disorder, associated with low self-esteem, depression, social anxiety, and sexual function disorders (Cooley, E \& Toray, T., 2001, p. 30).

Based on the background and also the identification of the problem that has been described, the formulation of the problem, Is there a relationship between celebrity worship with body image in adolescents who idolize K-pop at SMP Negeri 45 Bandung. 
The pattern of goals about body image varies, including aiming to uncover the relationship of body image with other variables such as selfconfidence (Wiranatha \& Supriadi, 2015; Putri, 2015; Hanipah, 2016; Amma, Widianti, Trishinta, 2017; Hakim, 2018), bodily satisfaction (Sari, 2007; Prawono, 2013; Octria, 2018), diet (Chairiah, 2012; Verawati, 2015; Oktaviyani, 2015; Savitri, 2015; Mulyani, Amir \& Astuti, 2016), dietary behavior (Husna, 2013; Caroline, 2013) , 2014; Chintyaningsih, 2015; Devegga, 2017). In addition, research patterns such as describing body image profiles in a population or community (Widiasti, 2016; Hudi, 2016; Wati \& Sumarmi, 2017; Inggi, 2016; Ashari, 2017).

In this study, the purpose of the study to be conducted at SMP Negeri 45 Bandung is to describe the relationship between celebrity worship and body image in adolescents who idolize K-pop at SMP Negeri 45 Bandung.

\section{METHODS}

This research was conducted with a quantitative approach. The quantitative approach in this study is used to describe, analyze, and draw conclusions about the general picture of celebrity worship and the body image of K-pop idol teenagers at SMPN 45 Bandung.

Participants in this study were K-pop idol teenagers at SMPN 45 Bandung. Nonprobability sampling is used for sample collection, researchers choose individuals because they represent several characteristics that researchers want to learn (Creswell, 2012, p. 145). Furthermore, researchers collected data according to sample criteria by purposive sampling, obtained a sample of adolescent research who idolized K-pop obtained as many as 111 teenagers.

The process of collecting data is by distributing celebrity worship instruments and body image instruments. The results of testing the validity of 30 items Celebrity Worship statement, it was found that 26 items were declared valid and 4 items were declared invalid. For the Body Image instrument namely the Multidimensional Body Self Relations QuestionnaireAppearance Scale (MBSRQ-AS), there were 2 items of categorical variables regarding perception and individual assessment of body weight so that it cannot be analyzed quantitatively. Based on data processing, from 23 statement items reduced again so that items are reduced to 22 statement items. The results of the validity test on 22 items of Body Image statement revealed 
that 15 items were declared valid and 7 items were declared invalid. The validity test uses the Rasch model application by looking at the Outfit Mean Square (MNSQ), Z-Standard Outfit (ZSTD), Point Measure Correlation (Pt Mean Corr), and Undimensionallity.

The reliability test results of the celebrity worship instruments from 26 statements that were said to be valid obtained an Alpha Cronbach value of 0.95 which indicates that the interaction between person and item as a whole is in the special category with a person reliability of 0.94 which means that it is very good and the value of item reliability is 099 , which means special. it can be concluded that both the consistency of the answers from respondents and the quality of items in the instrument falls into the reliable category.

The body image instrument reliability test results of 15 statements that are said to be valid obtain an Alpha Cronbach value of 0.71 which shows that the interaction between person and item as a whole is in good category with a person reliability of 0.67 which means that it is sufficient and the value of item reliability is 0,98 which means special. it can be concluded that both the consistency of the answers from respondents and the quality of items in the instrument falls into the reliable category.

The celebrity worship and body image categories are divided into three groups, namely low, medium and high. The categorization is obtained by using the calculation shown in table 1 and table 2.

Table 1

Categorization of Celebrity Worship Scores

\begin{tabular}{lll}
\hline No & \multicolumn{1}{c}{ Score Range } & Category \\
\hline 1 & $\mathrm{X} \geq($ Mean $+1,0 \mathrm{SD})$ & High \\
\hline 2 & $($ Mean $-1,0 \mathrm{SD}) \leq \mathrm{X}<($ Mean $+1,0 \mathrm{SD})$ & Medium \\
\hline 3 & $\mathrm{X}<($ Mean $-1,0 \mathrm{SD})$ & Low \\
\hline
\end{tabular}

(Azwar, 2017, p. 149)

Table 2

Categorization of Body Image Scores

\begin{tabular}{lll}
\hline No & \multicolumn{1}{c}{ Score Range } & Category \\
\hline 1 & $X \geq$ Mean & Positive \\
\hline 2 & $X \leq$ Mean & Negative \\
\hline
\end{tabular}

This research uses the Rasch Model measurement method by processing or analyzing all data through the use of the Winstep for Windows application. 


\section{RESULTS AND DISCUSSION}

\section{Overview of Youth Celebrity Worship tendencies that idolize K-pop at SMP Negeri 45 Bandung in 2018/2019 Academic Year}

Categorizing is done to find out the tendency of teen celebrity worship to idolize K-pop. An illustration of celebrity worship trends is presented in table 3.

Table 3

Frequency Distribution of Youth Celebrity Worship Tendencies that Kpop idols

\begin{tabular}{|c|c|c|c|}
\hline Score & Category & Frequency & Frequency \\
\hline$\geq 110$ & High & 24 & $21,62 \%$ \\
\hline $70 \leq X<110$ & Medium & 68 & $61,26 \%$ \\
\hline$<70$ & Low & 19 & $17,12 \%$ \\
\hline \multicolumn{2}{|c|}{ Total } & 111 & $100 \%$ \\
\hline
\end{tabular}

Based on the data frequency distribution table shows the general trend of teen celebrity worship who idolized K-pop SMPN 45 Bandung in the medium category. This means that teenagers tend to sometimes idolize activities on $\mathrm{K}$ pop idols. Like teenagers sometimes make K-pop idols a source of entertainment, sometimes make K-pop idols a source of social interaction, sometimes knowing about life the K-pop idol, sometimes has strong feelings for the K-pop idol, sometimes unable to control behaviour for the K-pop idol, and sometimes unable to control the fantasy about the idol.

Individuals with celebrity worship are being characterized by portraying their favourite idol as a life partner or always thinking about their idol under any circumstances. In this medium trend celebrity worship is characterized by more intense personal feelings, which are defined by behaviours such as "I often think of my favourite celebrities, even when I don't want to". This stage arguably reflects the intense and compulsive feelings of individuals around celebrities, similar to the obsessive tendencies of fans that are often mentioned in the literature (Dietz et al., 1991; Giles, 2000 in Maltby et.al, 2005, p. 20).

Maltby, Mc Cutheon et. al (2004) explains the characteristics of each inclination of celebrity worship which refers to each dimension of celebrity worship in measurement. Individuals with low celebrity worship are characterized by values, behaviour, and attitudes of individuals who are described as discussing what favourite idols have done with friends or like 
learning to understand the life story of a favourite idol is seen as a fun activity in their daily lives. The tendency of low celebrity worship has socialentertainment value and consists of attitudes and behaviours such as "I and friends are happy when they can discuss what my favourite celebrities have done". This stage reflects the social aspects of celebrity worship and is consistent with the observation of Stever (1991 in Maltby et.al, 2005, p. 20) that fans are attracted to favourite celebrities because of their ability to entertain and attract attention.

Individuals with high celebrity worship are characterized by individuals depicted as willing to spend money to buy equipment related to their idol or that has been used by their idol and if the idol asks to do something, the individual is willing to do it even if it is illegal and endangers him. The most popular acts of celebrity worship are labelled Borderline-pathological, as exemplified if someone gives him money to do what he wants, the individual will consider spending it on personal items that have been used by his favourite celebrity and will do something that can make me looks like his favourite celebrity.

\section{Trends in Body Image of Adolescents Who Idolize K-Pop}

Categorizing is done to find out the tendency of adolescent body image who idolizes K-pop. The categorization of celebrity worship trends is categorized into two categories, positive and negative. The description of the tendency of body image is presented in table 4 .

Table 4

Frequency Distribution of Tendencies of Body Image of Adolescents Who Idolize K-Pop

\begin{tabular}{ccc}
\hline Score & Category & Frequency \\
\hline$\geq 66$ & Positive Body image & 69 \\
& & $(62,16 \%)$ \\
\hline$\leq 66$ & Negative Body image & 42 \\
& & $(37,84 \%)$ \\
\hline \multirow{3}{*}{ Total } & 111 \\
& & $(100 \%)$ \\
\hline
\end{tabular}

Based on the overall frequency distribution table, the general tendency of adolescent body image to idolize $\mathrm{K}$-pop is in the positive body image category with a value of $62.16 \%$. It means that the teenager already has a good perception of his body, characterized by behaviour such as, seeing his body in accordance with the actual condition, adolescents respect their actual body and individuals understand that a person's physical appearance plays only a small 
role in showing their character, adolescents feel proud, satisfied and accept their body shape and adolescents feel comfortable and confident with their body condition.

Whereas negative body image is marked by feeling dependent to see himself in the mirror, not confident, thinking disparaging comments about his body, comparing his body shape with others, and feeling jealous of other people's bodies.

The results of the study are in line showing the results, body image has an average value of 76.74 so it can be said that body image in K-pop community members in Solo is in a positive category (53.5\%) (Noky, 2015). Other studies related to body image also show the same results, namely body image is in a positive category (Hakim, 2018).

In the personal development of adolescents there are several aspects that need attention, namely: 1) Devotion to God Almighty; 2) The acquisition of a value system; 3) emotional independence; 4) Development of intellectual skills; and 5) Accepting oneself and developing them effectively (Yusuf, 2014, p. 29).

The body image discussed in this study is related to one of the aspects above, namely the Aspect of Devotion to God Almighty. These points include 1) lack of ability to be patient and grateful (Yusuf, 2014, p. 28). Adolescents with the above criteria are aimed at adolescents who view the state of their body or negatively assess the state of their body as indicated by adolescents who do not accept or are not satisfied with the state of their bodies which means that adolescents do not show grateful behaviour. Treated with adolescents who do various things or attempt to make their body shape as they wish in extreme ways such as on a strict diet, strict exercise, and plastic surgery which shows that teenagers do not have the patience to make changes to the state of his body.

In addition, the body image discussed in this study is related to one of the aspects above as well as the aspect of accepting yourself and developing it positively. These points include; 1) Feeling less proud of yourself and 2) Feeling inferior, when associating with others who have strengths (such as more beautiful/handsome friends) (Yusuf, 2014, p. 29). For adolescents who have the characteristics of the above criteria, it shows that the teenager does not yet have satisfaction with his own situation, especially on the physical condition related to body image. Conversely, teenagers who feel proud of their 
condition and feel confident when associating with other people who have strengths, it is because there are a positive assessment and self-understanding of the advantages and disadvantages. In accordance with the statement according to Suherman (2015, p. 17) which is one of the tasks of the development of the personal field of the individual is to have a positive, objective and constructive understanding and self-acceptance, both related to the advantages and disadvantages of both physical and psychological. An individual's assessment of his body state or what is called a body image can be assessed in the form of a positive and negative assessment which means that body image consists of two characteristics namely positive body image and negative body image.

\section{Relationship between Celebrity Worship and K-pop idolized teen's body image}

Based on the results of the SPSS program analysis using Pearson's productmoment to find out the coefficients between the celebrity worship variables and body image can be seen in Table 5 below.

Table 5

\section{Correlation Between Variables}

Correlations

\begin{tabular}{|c|c|c|c|}
\hline & & $\begin{array}{l}\text { Celebrity- } \\
\text { Morstip }\end{array}$ & Body Image \\
\hline \multirow[t]{3}{*}{ Celebrity_Morship } & Pearson Correlation & 1 & $.210^{\prime}$ \\
\hline & Sig. (2-tailed) & & .027 \\
\hline & N & 111 & 111 \\
\hline \multirow[t]{3}{*}{ Body_Image } & Pearson Correlation & $.210^{\prime}$ & 1 \\
\hline & Sig. (2-talled) & .027 & \\
\hline & N & 111 & 111 \\
\hline
\end{tabular}

*. Correlation is significant at the 0.05 level (2-tailed).

The calculation results show the correlation value of celebrity worship with body image (rxy) of -0.21 . Significant value of $p=0.027<0.05$ so that the correlation coefficient is stated significant. This shows that there is a significant negative relationship between celebrity worship and body image. meaning the lower the celebrity worship, the higher the body image. 
conversely, the higher the celebrity worship, the lower the body image. With a significant value of $\mathrm{p}=0.027<0.05$, then Ho is rejected, meaning that there is a significant negative relationship between celebrity worship and body image.

Based on the hypothesis test, the results show that there is a significant negative relationship between celebrity worship and body image. it means that the lower the celebrity worship, the higher the body image of teenagers who idolize K-pop at SMPN 45 Bandung in 2018/2019 Academic Year. Conversely, the higher the celebrity worship, the lower the body image of teenagers who idolize K-pop. The results of this study are in line with research conducted by Noky (2015) which says that there is a significant negative relationship on the dimensions of social entertainment and the dimensions of intense persona feeling with body image.

In previous research that has been done, Maltby et al (2005) found a significant relationship between celebrity worship behavior with body image, especially for adolescent girls aged 14 to 16 years, while in male participants, Maltby et al did not find any significant relationship with body image ( Maltby et al., 2005). With the form of body image shown by celebrities or models that may not be able to be followed by adolescents, can trigger pathological conditions that adversely affect adolescents (Maltby et al, 2005). In this study, it was also found that female adolescents with a vulnerable age of 14 to 16 years who are in the intense-personal aspect and boast a feeling for the shape of the body that is loved by people, is a characteristic of adolescents who develop a poor body image of themselves.

Celebrity worship is excessive admiration and attachment to certain idols, whose personal attributes are too inclined or idealized (Fromm, 1967 in Liu, 2013, p. 15). The intended personal attributes are physical, especially body image related to this research. Celebrity worship usually involves one or more celebrities who are very liked by individuals so that individuals can not seem to be separated from things related to the celebrity. Teenagers feel they already have an attachment in the form of a relationship with their idol specifically so they want to be as close as possible and as ideal as possible to match their idols.

One of the factors that influence celebrity worship is body image. Body image is one's perception, thoughts and feelings about one's own body (Grogan in Nanu, 2014, p. 2). These perceptions, thoughts and feelings are evaluated positively and negatively. A positive body image is an accurate and true mental image of the body, along with positive feelings, measurements, 
and relationships with our body, self-confidence, and care for the body, meaning that the teenager has a proper picture of his body that is in accordance with his state, feels comfortable and satisfied. Positive body image plays an important role in encouraging healthy physical and psychological development in adolescents. Individuals who are able to evaluate their body positively or can accept and feel satisfied with the state of the body they have will reduce the behaviour of celebrity worship that tends to negatively affect the body image.

Negative body image means there are problems in personal development in adolescents, namely the aspect of accepting oneself and developing it effectively (Yusuf, 2014, p. 29). Negative body image means someone's dissatisfaction with some aspects of their appearance (Cash, in Cash \& Fruzinsky, 2002, p. 269) in other words, there are several aspects of one's appearance that are evaluated negatively. A negative body image means that the adolescent is not satisfied with the state of his body and has not yet accepted his true self. In accordance with the statement (Yusuf, 2014, p. 29) personal issues related to this matter are; 1) Feeling less proud of yourself and 2) Feeling inferior, when associating with others who have strengths (such as more beautiful / handsome friends) (Yusuf, 2014, p. 29). Suherman (2015, p. 17) also suggested that one of the tasks of the development of the personal field of the individual is to have a positive, objective and constructive understanding and self-acceptance, both related to the advantages and disadvantages of both physical and psychological.

Not all values given by idols are positive, one of which is an ideal body shape that is difficult to achieve, so teenagers who are in transition try to do anything to mimic their idol's good looks even though it is not easy. Sheridan et al (2007) concluded that someone who worships celebrities tends to look for their identity and identify with the celebrity. So with the behaviour of celebrity worship can affect various things in a person's life as well as about the body image.

\section{CONCLUSIONS}

Based on the research results of the trend of teen celebrity worship who idolized K-pop SMP Negeri 45 Bandung Academic Year 2018/2019 are in the medium category. This means that teenagers sometimes do idol activities on K-pop idols. This shows that many adolescents sometimes perform idol activity in certain conditions and situations depending on the desire of 
adolescents to idolize. Based on the dimensions of adolescents who idolized K-pop Bandung 45 Junior High School Academic Year 2018/2019 obtained the highest average in the dimension of entertainment social value. This means that teenagers often do idol activities. This shows that adolescents often perform idol activities as a source of entertainment for themselves.

The results of the study of the tendency of body image of adolescents who idolize K-pop of SMP Negeri 45 Bandung in 2018/2019 Academic Year are in a positive category. This means that adolescents already have a good perception of their body, characterized by behaviors such as, seeing their bodies in accordance with their actual conditions, adolescents respect their actual bodies and individuals understand that a person's physical appearance only plays a small role in showing their character, adolescents feel proud, satisfied and accepting form his body and teenagers feel comfortable and confident with the condition of his body. This shows that adolescents have good perceptions regarding body size, shape and aesthetics based on individual evaluations are already at a good level.

There is a significant low and negative relationship between celebrity worship and body image. Negative relationships show that there is a unidirectional relationship between celebrity worship and body image. This means that the lower the celebrity worship, the higher the body image. conversely, the higher the celebrity worship, the lower the body image. this shows that idolizing does not always affect adolescents' views of their bodies. Teenagers also understand the difference between his idol activities and his true state.

The results showed the relationship between celebrity worship and body image had a low relationship strength. Guidance and counselling teachers can help students improve the problem of negative body image of students with a focus on developing negative body image into a positive body image and can ignore the celebrity worship factor because a low relationship means celebrity worship does not have much influence on students' perceptions about the body image.

Research recommendations for further research include involving other variables to test the strength of the correlation, can conduct research on adolescents who are members of the K-pop community and can conduct research on individuals who idolize idols or other figures other than K-pop idols. 


\section{REFERENCES}

Cash, Thomas F \& Pruzinsky T. (2002). Body Image: A Handbook of Theory, Research, and Clinical Practice. New York: Guildford Press.

Cooley, E. \& Toray, T. (2001). Body image and personality predictors of eating disorder symptoms during the college years. Int J Eat Disord, $30(1), 28-36$.

Dacey \& Kenny. (2001). Adolescent Development (second edition). New York: Mc Graw Hill.

Departemen Pendidikan Nasional. (2008). PenataanPendidikan Profesional Konselor Dan Layanan Bimbingan dan Konseling Dalam Jalur Pendidikan Formal. Jakarta.

Frederika, E, dkk. ( 2015). Hubungan antara harga diri dan konformitas dengan celebrity worship pada remaja di Surabaya. Jurnal Gema Aktualita, 4 (1), 61-6911.

Hakim., L., Z. (2018). Pengaruh Citra Tubuh Dengan Kepercayaan Diri. (Skripsi). Departemen Psikologi Pendidikan dan Bimbingan FIP UPI. Bandung: Tidak Diterbitkan.

Liu, K. (2013). Idol worship, religiosity, and self-esteem among university and secondary student in Hongkong. Discovery-SS Student E-Journal, 2 (13), 15-28.

Maltby, J, et al. (2005). Intense-personal celebrity worship and body image: Evidence of a link among female adolescents. British Journal of Health Psychology, 17-32.

Maltby, J,. (2004). Personality and coping: A context for Examining Celebrity Worship and Mental Health. British Journal of Psychology.

Nanu, C., Taut, D. \& Baban, A. (2014). Why adolescents are not happy with their body image?. Analyze journal of gender and feminist studies, 4 (2), $1-20$.

Nerissaputri, K. (2015). Fenomena Operasi Plastik yang Dilakukan Individu Terkait Tren Budaya Korea yang Sedang Berkembang. (Skripsi). Fakultas Ilmu Sosial dan Ilmu Politik UI. Depok : Tidak Diterbitkan.

Ninggalih. (2011). Waspada demam idola. Diakses dari : http://majalah1000guru.net/2011/10/waspadai-demam-idola/.

Noky., M.,H. (2015). Hubungan Celebrity Worship Pada Idola K-pop Dengan Body Image Di Komunitas K-pop UCEE. (Skripsi). Fakultas 
Psikologi Universitas Kristen Satya Wacana. Salatiga : Tidak Diterbitkan.

Rombe, S. (2014). Hubungan body image dan kepercayaan diri dengan perilaku konsumtif pada remaja putri di SMA Negeri 5 Samarinda. E jurnal psikologi, 2 (1), 76-91.

Santrock, J. W. (2012). Life-span development: Perkembangan masa hidup (Edisi ketigabelas). Alih bahasa oleh Benedictine Widyasinta. Jakarta: Erlangga.

Sheridan, L., North, A., Maltby, J., Gillett, R. (2007). Celebrity Worship addiction and criminality. Psychology, Crime \& Law. 13(6) : 559571 .

Suherman, Uman. (2015). Manajemen Bimbingan dan Konseling. Bandung : Rizqi Press.

Sunarni. (2015). Pengaruh Celebrity Worship Terhadap Identitas Diri Remaja Usia SMA Di Kota Yogyakarta. (Skripsi). Departemen Psikologi Pendidikan dan Bimbingan FIP UNY. Yogyakarta : Tidak Diterbitkan.

Yusuf, Syamsu,. LN \& Nurihsan, J. (2014). Landasan Bimbingan dan Konseling. Bandung : Rosdakarya 